\title{
Developing a University Learning, Teaching and Research Framework Through Practice Conversations
}

\begin{tabular}{|r|l|}
\hline Journal: & Journal of Applied Research in Higher Education \\
\hline Manuscript ID & JARHE-11-2020-0380.R1 \\
\hline Manuscript Type: & Research Paper \\
\hline Keywords: & $\begin{array}{l}\text { Action research, Research in practice, Design principles, Learning, } \\
\text { teaching and research framework, Practice conversations }\end{array}$ \\
\hline \multicolumn{2}{|l}{} \\
\hline
\end{tabular}

\section{SCHOLARONE \\ Manuscripts}




\title{
Developing a University Learning, Teaching and Research Framework Through Practice Conversations
}

\begin{abstract}
Study design/methodology/approach: This action research project provided a process for university community members to engage in practice conversations. In phase 1 , focus groups and campus community discussions elicited the diverse perspectives of the community. The design-thinking process of discovery, ideation, and prototyping aligned with the action research cycles to help a working group create a learning and teaching framework prototype based on the findings. In the second phase, surveys were used to elicit community members' responses to the prototype, which was then refined.
\end{abstract}

Purpose: This project engaged faculty, students, alumni, and staff in re-visioning their university's learning, teaching, and research framework. An extensive consultation process allowed participants to explore, discuss, and critically reflect on effective practice.

Findings: The prototype was organized into three overarching categories, each containing several attributes. The attributes of the "Applied and Authentic" category were: interdisciplinary and transdisciplinary; experiential and participatory; flexible and individualized; outcomes based; and openly practiced. The attributes of the "Caring and Community-Based" category were: inclusive and diverse; community-based; supportive; team-based; co-creative; and place and virtual space-based. The attributes of the "Transformational" category were socially innovative; respectful of Indigenous peoples and traditions; impactful; and reflective. 
Originality/value: This article should interest higher education institutions seeking to engage faculty, staff, students and others in practice conversations to develop a learning, teaching and research strategy. This research demonstrated that fostering practice conversations among diverse community members can be a powerful process for creating a common and integrated vision of excellent learning, teaching, and research practice.

\section{Introduction}

Engaging faculty and other stakeholders in systematic dialogue about teaching and learning practices can enhance an institution's practice and promote "better understanding between different layers of the institution" (Stensaker et al., 2017, p. 13). This article describes an action research project that fostered systematic dialogue among educational practitioners. Kemmis (2012) terms such practitioner conversations "research in educational praxis", since they involve practitioners who understand their practice from inside their experience (p. 896). By fostering practice conversations, this project meaningfully engaged Royal Roads University's (RRU) community members to review and revise its learning and teaching framework. This article describes the research process and the characteristics of several learning and teaching frameworks as well as pertinent action research literature. It concludes with an overview of the outcomes, which are presented as the Learning, Teaching and Research Model. This article describes a process that creates a common and integrated vision of excellent learning, teaching, and research practice. This process can be adapted and applied in other institutions. 
Since its inception in 1995, RRU, a small Canadian public research university, has worked to differentiate its approach to learning and teaching. However, what characterized teaching and learning at RRU was not systematically explored and documented until the development of the Learning and Teaching Model (LTM) (Hamilton et al., 2013). The LTM "[a]rticulated a common and institutional understanding of the unique mix of history, learning approaches, curriculum, teaching strategies, and educational practices that give rise to a particular institutional identity" (Hamilton et al., 2016, p. 18). Its success and adoption by the university community laid the groundwork for the research project described in this article.

This project came was the result of faculty and staff members' requests to revisit and update the LTM. RRU's learning and teaching practice had evolved, and a new learning and teaching framework was needed to provide direction in the context of rapid changes in educational technology and the higher education landscape. The project aimed to benefit from the university community's knowledge and passion for learning and teaching. This project also allowed those who had joined RRU since the LTM had been completed, many of whom had been attracted to the university for its distinctive learning and teaching approach, the opportunity to reshape it.

\section{Learning and Teaching Frameworks}

Learning and teaching frameworks are referred to by many names, such as plans (Bozalek and Dison, 2013), strategies (Abertay University, 2015), guidelines (University of New South Wales, 2014), guiding principles (Chang, 2008), action plans (Queens University, 2014), and frameworks (Carleton University, 2014; University of Calgary, 2014). While each has a unique focus, they invite faculty to reflect on their 
teaching practice and engage in conversations on the teaching values that define their work at an institutional level (Harris et al., 2019).

Learning and teaching frameworks can be outwardly focused to create a positive external perception. For example, some institutions use their frameworks to promote their institutional values and differentiators (Abertay University, 2015; Bük et al., 2017; Carleton University, 2014). Others use them to profile the value that the organization places on the teaching role (Bozalek and Dison, 2013).

Learning and teaching frameworks may have a predominantly internal focus, which specifically benefits staff, faculty, and students. For example, several institutions identify a key focus for the implementation of their frameworks as supporting teaching excellence (Abertay University, 2019; Mount Royal University, 2019; Steel and Jeffreys, 2006; University of Calgary, 2011), with faculty training, professional development, and new faculty orientation stated as activities that aid in the achievement of this purpose (Baik et al., 2018; University of Melbourne, n.d.; University of New South Wales, 2019). Curriculum reform is another internal purpose (Robertson, 2016), which adds credibility to the role of teaching and learning (Bozalek and Dison, 2013). Brew (2010) discussed the benefits of compiling a database of best practices in teaching, referring to the advantages achieved by linking research to teaching, for example, increased student awareness of research, as well as providing opportunities for faculty and staff to profile their research. However, the benefits to students extend beyond their awareness of research and include supporting student success by creating an environment that encourages enhanced engagement (Carleton University, 2014; Looker, 2005), student interaction (Chang, 2008), and promoting interdisciplinary teaching practices (University 
of Melbourne, 2007; University of Sydney, 2016). Furthermore, some institutions offer guidelines to provide faculty with an understanding of student attributes, as well as how to approach the development and implementation of learning outcomes (University of the Western Cape, n.d.).

RRU's framework, the LTRM, is externally focused, communicating what differentiates its learning, teaching, and research, and inwardly focused, documenting the results of the broader community consultations.

\section{Action Research Design}

While stakeholder consultation is often a part of developing strategic documents, the action research design of this project added substantial rigour to the process, providing a foundation of established and tested research tradition, with documented features, principles, ethics and protocols. As a formal action research project, stakeholders' roles moved beyond providing input to that of research "co-definers, codesigners and co-implementors (Bradbury, 2015, p. 2).

An action research approach aligned with the aims of the project: (a) to address an opportunity significant to stakeholders; (b) to benefit from their experiences, knowledge, and passion to ensure ownership and fit; (c) to promote social learning through dialogue and, (d) to create infrastructure (Bradbury and Reason, 2003, p. 155), specifically a new learning and teaching model. Action researchers necessarily work with practitioners because action research takes place in a context of practice (Bradbury-Huang, 2010). This "insider action research" project (Coghlan and Shani, 2015 , p. 47) took place with practitioners in a university context of teaching and learning practice. It promoted dialogue among practitioners, the sharing of experience and 
knowledge, and critical reflection on concepts, practices, values, and emerging trends in higher education. Dialogue about what participants valued in the organization's, and their own teaching and learning practice, facilitated the learning of other practitioners (Coghlan and Brannick, 2010). These conversations also encompassed praxis, defined as "educational action" of benefit, "informed by traditions in the field" and "with moral, social, and political consequences - good or bad - for those involved and affected by it" (Edwards-Groves et al., 2018, p. 12).

Kemmis (2010) argues that:

Practice/praxis is only researchable 'from within', by people whose practice it is, either as individuals reflecting on their own practice with a view to transforming it, or as collectivities like communities that constitute a profession with a view of transforming it. (p. 18)

As researchers, we place ourselves firmly in the camp of "research in [rather than on] educational praxis" (Kemmis, 2012, p. 896). However, because many stakeholders had direct involvement in the creation of a holistic student experience, we extended the exclusive focus from faculty practice/praxis research, to also include support staff, contract faculty, students, alumni, advisory councils, and executive. Because we aimed to tap into the collective energy, passion, and expertise within the wider community, they needed to be included and empowered to contribute. The inclusive, participative, and collaborative design of this project was also important to creating a sense of shared or "front-line ownership" (Zimmerman, et al., 2013).

"Action research is a pragmatic co-creation of knowing with, not about, people" (Bradbury, 2015, p. 1, author's emphasis). This project was initiated in response to calls 
by university community members to engage in a process to review and revise an existing learning and teaching model, to engage in a co-creation with the people who lived it in practice. Its cyclical and iterative design ensured numerous opportunities to contribute meaningfully and fully at every stage of the research (Ivankova, 2015), and to participate in an emergent meaning-making process within the complex system of the multiple stakeholder groups within the organization. As Lichtenstein (2015) states: ... the drivers for organizational emergence are aspiration and passion -the vision and enactment of a new idea that can lift the organization to a new level, to create more value than it currently does. The origin of emergence is a potentiality, a spark of creativity, an open-ended possibility that can be enacted in myriad ways. (p. 451)

In designing a co-creative, inclusive, and iterative process, we aimed to benefit from the passion of the practitioners for their practice, their aspirations for themselves as educators and for the organization, and to engender that spark of creativity that emerges when passionate and committed practitioners talk about possibilities.

Silverman's (2015) concept of "designerly ways as practical skills for action research skills" (p. 717) helped the researchers to conceive of this project as a process of iterative proto-typing and testing. The project design incorporated three iterative action research cycles of observation, reflection, and action (Stringer, 2014, p. 9), each aimed at providing opportunities to gain diverse perspectives of RRU community members and to maximize opportunities for ongoing engagement and feedback from members of the RRU community. The design principles of discovery, ideation, and prototyping, followed by iterative cycles of reviewing and refining the prototype 
(Silverman, 2015, p. 718) aligned with the action research cycles and allowed the team to prototype and refine the model (Table 1).

\begin{abstract}
[Insert Table 1 here]
Methods

The action research took place over two years and was led by a working group of 10 faculty and staff who were involved in planning, data collection and analysis, and prototyping. The first consultation activity was a Maker Day (Crichton and Carter, 2015), an immersive, interactive design thinking activity which called on participants to design and build a visual metaphor for learning and teaching at RRU. Forty-eight RRU staff and
\end{abstract} faculty participated. Their metaphors were photographed, and flip charts notes recorded and summarized key ideas in a debrief conversation.

Subsequent focus groups were held to gain a deeper understanding of community members' perspectives on, and experience with effective learning and teaching practices. Multiple focus groups were conducted with: (a) faculty; (b) faculty who teach international students; (c) faculty and staff discussing research; (d) staff; (e) student services staff; (f) students; and (g) alumni. The research focus groups led to research receiving a more prominent place in the model and the name change to the Learning, Teaching, and Research Model.

Other sources of data were also reviewed: feedback from school advisory councils and university executive; data from existing student and alumni surveys; brainstorming and feedback discussions at several campus-wide activities; and interviews with faculty members with specialist knowledge. 
The LTRM project used an open data strategy, whereby anonymized data notes and summaries were made accessible to the RRU community using a WordPress site. Community members were encouraged to access this site and provide feedback. This engagement strategy allowed members of the community to continue to make meaning of and share their learning.

\section{Data Analysis and Prototype Building}

In phase 1, a working group member conducted initial coding of the raw data using NVivo 11 to identify emergent themes. This member created data summary notes and placed them on the LTRM WordPress site for review and comment by the broader community. The initial codes, raw data, and summary notes of focus groups were also individually reviewed by all working group members, who then met in a series of workshop sessions to review the data and come to agreement on the overarching themes and the elements that needed to be included in a prototype.

Drafting a visual prototype which best organized and presented the themes and elements in the data was the most challenging and time-consuming part of the process. Over several meetings, the working group drafted three prototypes. The merits and drawbacks of each was exhaustively debated before the Working Group finally came to consensus on the LTRM prototype that best organized and represented the themes identified in the data.

Phase 2 of the action research cycle (table 1) was to verify that the working group's interpretation of the data and the resonance of the prototype with university community members. The working group circulated a graphic of the prototype and solicited feedback by survey from all members of the university community. The survey results 
were analyzed, and the results were used to revise and refine the prototype and create the current LTRM model (Phase 3 of the action research cycle). The comprehensive consultation across multiple stakeholder groups rapidly led to data saturation, with themes repeating across the data sets. The feedback we received on the prototype reinforced the trustworthiness of our findings.

\section{Findings}

The prototype presented three overarching themes (which we called core value categories): (a) Applied and Authentic; (b) Caring and Community-Based; and, (c) Transformational. Each category contained four to six specific attributes which further defined the categories (Table 2).

[Insert Table 2 here]

The next section describes the core value categories, associated attributes and includes illustrative quotations from the data. Table 3 lists the source of these quotations and the abbreviations used to identify the source of these in the data.

[Insert Table 3 here]

\section{Applied and Authentic}

The core value category "Applied and authentic" describes learning, teaching, and research practices that aim to have positive impacts on the real situations. This category refers to students learning through working with real-world issues, rather than learning about something. These often messy and ill-defined issues take place in communities, workplaces, or in regional or global settings. This category also applies to learning in workplace or community settings. Similarly, research aims to create practical and positive outcomes in the real world. Five attributes identified under this broad 
category included: (a) interdisciplinary and transdisciplinary; (b) experiential and participatory; (c) flexible and individualized; (d) outcomes-based, and (e) openly practiced.

Interdisciplinary and transdisciplinary. Staff commented that this attribute applies across programs rather than just in specific programs. It "allows for an environment of divergent thinkers which then facilitates deeper understanding of current and relevant topics, and also supports students as they learn to approach complex problems with a critical lens" (Staff FG).

Experiential and participatory. This attribute speaks to facilitating a learning environment and processes that foster students' active participation in knowledge construction through examining real-world challenges and applying theory and research to problem-solving. "RRU is about experiential learning informed by research and enabled by practice" (AC Feedback).

Flexible and individualized. This attribute is enacted in two ways. First, it allows non-traditional applicants, for example, someone without an undergraduate degree required for standard admission into master-level programs, but with related learning through work experience, to enter a program. For example, one student stated that "If it weren't for flexible admissions, I could never have had this experience" (Student FG). Second, this attribute recognizes student demand for the ability to customize learning to fit with their needs. Programs are collaborating across faculties and schools to provide more optional specializations and electives to build capacity for students to adapt learning to meet their needs. 
Outcomes-based. Learning outcomes identify exactly what a student should be able to do as a result of the learning. As one participant observed, outcomes-based "assessments are based on authentic activities and outcome-based curricula ensure engaged and well-focused design of learning experiences" (Alumni FG).

Openly practiced. This attribute refers to the social learning aspect of RRU curricula, the growing trend of using open and participatory approaches to facilitate working together, and the use of open resources and open research to increase access and equity. An example of this is the creation of the first zero-textbook cost (ZTC) master's program in Canada.

\section{Caring and Community-Based}

Caring "plac[es] the human at the center and intentionally building relationships based on trust and respect" (Harris et al., 2019, p. 17). The result is a "warm, and inclusive culture" (Faculty FG) grounded in relationships built on respect, trust, "caring and community" (Alumni FG). Caring includes building a safe and inclusive environment that supports students, faculty, alumni, and staff to learn and grow. Staff observed, "we live it, creating a respectful, inclusive, and welcoming atmosphere" (Staff FG). Caring was extended to the local and global communities by many participants who recognized the intentional efforts of RRU to "make positive changes in the world, [and] using the actual process of learning to affect change" (Staff FG). Others observed similarly that "RRU research starts with a social problem and draws on appropriate different approaches (inter/trans) to solve. The environment here allows us to do that" (Research FG). Six attributes were identified under this core value category: (a) inclusive and 
diverse; (b) community-based learning; (c) supportive; (d) team-based; (e) co-creative, and (f) place- and virtual space-based.

Inclusive and diverse. This attribute refers to learning environments in which diverse backgrounds, experiences, and perspectives are valued irrespective of race and ethnicity, gender, sexual orientation, and different abilities. Such environments are evidence of a "warm and inclusive culture" (Faculty FG). Faculty, students, and staff saw the importance of learning environments that encourage the exploration of multiple and diverse perspectives. In RRU research, it refers to meaningful engagement of communities in and dialogue about relevant community-based issues, which characterize "collaborative, empowering, relational research and teaching. Doing research with people in a collaborative way" (Research FG).

Community-based learning. A safe community grounded in mutually beneficial relationships is at the core of this attribute. A student observed, "This was by far the most supportive academic community I have ever been a part of" (Student Survey). This mutually supportive community focus is fostered through the work of faculty and staff in their teaching, learning, and support work. It is demonstrated by the research conducted at $R R U$, including the role of community in conceptualizing a research topic.

Supportive. This attribute captures a learning environment and the shared responsibility for engagement, guidance, and feedback taken up by faculty, staff, learners, and researchers. Many participants from a variety of stakeholder groups saw the creation of safe and inclusive learning environments, and a supportive approach as an essential characteristic of RRU. 
Team-based. Skills and competencies in collaboration, effective teamwork, and the appreciation and inclusion of multiple perspectives characterize this attribute. While students spoke of teamwork as a "challenging process", they also saw its value. "Learning is accelerated in a team environment" (Student FG). Teamwork is woven throughout the curricula, and support is provided for working in teams. In addition, several students noted the positive impact of working on diverse teams, stating "working closely with many people of varying ages, experience, and views helped me to balance my understanding" (Student Survey). The interaction of faculty, staff, and students in interdisciplinary teams provides multiple perspectives to real-world learning challenges.

Co-creative. This attribute recognizes and draws on the experiences and knowledge of all who are part of the teaching, learning, and research endeavors. The "teamwork and co-creation [of learning experiences] is already a differentiator for RRU" (Alumni Survey).

Place-based and virtual space-based. This attribute recognizes that teaching, learning, and research takes place at the physical campus location as well as the virtual campus and supporting virtual environments in which students, staff, and faculty do their work. One participant stated, "I appreciate the revised section ... 'place/virtual space', because I think this reflects the ways in which we create community through physical and digital spaces" (Staff Survey). Community and relationships are built, enhanced, and sustained in both physical and virtual environments.

\section{Transformational}

The third core value category identified was "Transformational", which is defined as seeking "to develop in students a socially innovative mindset capable of generating 
systemic, sustainable, creative solutions to social challenges and changes, including challenges related to the environment, education, health, and business" (Harris et al., 2019 , p. 20). One participant captured the centrality of transformation, noting, "as the world transforms, we must all be prepared for a lifetime of transformative change" (AC Feedback). A student observed that "a transformational learning process ... provided space for people to grow and reinforce their learning" (Student FG). A faculty member described the connection between transformation and real-world problems, saying "We live it. There is demonstration of 'being, knowing, relating, transforming', and addressing real world problems" (Faculty FG).

Four attributes identified under this broad category included: (a) socially innovative; (b) respectful of Indigenous peoples and traditions; (c) impactful, and (d) reflective.

Socially innovative. Participants identified the value of connecting the practical with the theoretical, stating "the role of social innovation, real-world problem solving, and the use of scholar-practitioners who can provide the context and 'reality check' for learners" (Faculty Survey). Students described "an immersive and transformative quality in the experience of engaging in practical action research" (Student FG), which enhanced their learning experience.

Respectful of Indigenous peoples and traditions. This attribute speaks to the role of curriculum in transforming views and breaking down barriers to "co-imagine a curriculum that includes but also learns from Indigenous principles and history, and ... offer[s] students opportunities to experience Indigenous ways of knowing and being" (Harris et al., 2019, p. 20). It implies working together in a good way. This attribute is 
"intended to ensure social justice underpins all we do - take down the fences and build bridges" (LTRM activity).

Impactful. This attribute addressed various aspects of change leadership across social, environmental, political, and organizational contexts. Not surprisingly, 'changemaking' is a notable theme at a university designated as an Ashoka $U$ Changemaker Campus (https://ashokau.org/changemakercampus/campuses/); as a result, staff discussed the students' role in the change-making process, "Our students are changemakers, even at the undergraduate level" (Student Services FG). An alumnus reinforced this by commenting, "the learning came first, supported by shared values and understanding that allowed for me and my classmates to go out and 'do the why"' (Alumni Survey). The applied focus and nature of the RRU programs allows students to use the theory in a practical situation to make a positive difference.

Reflective. Reflective practice is a critical part of transformational learning. Reflecting on self brings insight and understanding of new ways forward. A student remarked that, "Often I would realize only upon reflection that I was doing/seeing/approaching my experiences differently. The learning strategies facilitated this easily" (Student Survey).

\section{Reflection and Implications for Practice}

Action research aims to address an issue specific to the context in which the research was conducted, so the authors recognize that the findings are not generalizable to other settings without adaptation. However, this article presented insights into an adaptable process that can be applied in other institutions seeking to benefit from practitioners' engagement, insights, and knowledge. 
This project had several challenges. It took two years to complete, a long time in institutional life. While data gathering took place over three months, the working group's intensive work of analysis, deliberation and building consensus took longer than anticipated. At times, it was difficult to schedule working group meeting times, since the researcherl were participating in addition to the demands of their regular work, and, at times, this negatively impacted momentum of the project. Further, not surprisingly, the extensive consultations with multiple stakeholder groups produced a great deal of data. While the working group had anticipated this issue, we felt it was necessary to ensure that all RRU community members had several opportunities to contribute and feel heard. To apply this process elsewhere, project leaders need to consider ways to address this issue, perhaps by freeing up faculty and staff time for the work.

The university had several characteristics that supported this action research project. Faculty and staff had called for the consultative process, which demonstrated that their valuing of, and commitment to, the process. As well, as a small university with inter- and trans-disciplinary programs and an applied research agenda focused on making positive change in the world, the "practice challenge" (Stensaker et al., 2017, p. 10) that arises from the disciplinary variations in conceptions of teaching, learning and research is greatly reduced. Applying the LTRM project's research-in-practice approach (Kemmis, 2012) to larger, more disciplinarily diverse institutional settings would require a strategy for dealing with these disciplinary variations.

This research project demonstrated that fostering practice conversations among diverse university community members can support creating a common and integrated vision of excellent learning, teaching, and research practice. The consultative process 
allowed university community members to explore, discuss, and critically reflect on effective learning, teaching, and research practices. The numerous interactions amongst community members, opportunities to explore data using an open data approach, and provide input on the draft prototype were crucial to creating deep engagement. The action research and design-thinking approaches used allowed for maximum participation and provided a transparent, democratic process for deep engagement in the teaching, learning and research strategy aligned with the culture of the RRU community.

\section{References}

Abertay University. (2015). "Strategic plan 2015 - 2020", available at: https://www.abertay.ac.uk/about/the-university/purpose/ (accessed 15 October 2020)

Abertay University. (2019). "Teaching and learning enhancement", available at: https://www.abertay.ac.uk/about/working-at-abertay/teaching-and-learningenhancement/ (accessed 15 October 2020)

Baik, C., Naylor, R., \& Corrin, C. (2018). Developing a framework for university-wide improvement in the training and support of 'casual' academics. Journal of Higher Education Policy and Management, Vol 40 No 4. pp. 375-389. Available at: https://doi.org/10.1080/1360080X.2018.1479948 (accessed 15 October 2020) Bozalek, V., \& Dison, A. (2013). Using the human capabilities approach as a normative framework to evaluate institutional teaching and learning interventions at UWC. South African Journal of Higher Education, Vol 27 No 2. pp. 383-400. 
Bradbury, H. (2015). Introduction: how to situate and define action research. In Bradbury, H. (Ed.) The Sage Handbook of Action Research (3rd ed.) Sage, London, UK. pp. 1-9.

Bradbury, H., \& Reason, P. (2003). Action research: an opportunity for revitalizing research purpose and practices. Qualitative Social Work, Vol 2 No 2. pp. 155175.

Bradbury-Huang, H. (2010). What is good action research? Why the resurgent interest? Action Research, Vol 8 No 1. pp. 93-109.

Brew, A. (2010). Imperatives and challenges in integrating teaching and research. Higher Education Research \& Development, Vol 29 No 2. pp. 139-150. Available at: https://doi.org/10.1080/07294360903552451 (accessed 15 October 2020)

Bük, T., Atakan-Duman, S., \& Pasamehmetoğlu, A. (2017). The university identity: communication of identity themes. International Business and Accounting Research Journal, Vol 1 No 2. pp. 55-70. https://doi.org/10.15294/ibarj.v1i2.8 (accessed 15 October 2020)

Carleton University. (2014). Towards an integrated academy: a teaching and learning framework for Carleton University 2013-2018. Available at: https://carleton.ca/teachinglearning/wp-content/uploads/A-Teaching-andLearning-Framework-for-Carleton-University.pdf (accessed 15 October 2020) Chang, S. (2008). Facilitating local-international student interaction and integration through curriculum development. Paper presented at the ISANA International Education Aukland, New Zealand. Available at: https://www.researchgate.net/profile/Shanton_Chang/publication/281271305 Fa 
cilitating local-

international student interaction and integration through curriculum developm ent/links/55ddbcaf08ae7983897cffb2/Facilitating-local-international-studentinteraction-and-integration-through-curriculum-development.pdf (accessed 15 October 2020)

Coghlan, D. \& Brannick, T. (2010). Doing action research in your organization. (3 $3^{\text {rd }}$ ed.) Sage, London, UK.

Coghlan, D. \& Shani, A. (2015). Developing the practice of leading change through insider action research: a dynamic capability perspective. In Bradbury (Ed.) The Sage Handbook of Action Research (3rd ed.) Sage, London, UK. pp. 47-54.

Crichton, S. \& Carter, D. (2015). Taking making into the schools: an immersive professional development approach. In M. Niess \& H. Gillow-Wiles (Ed.s). Handbook of Research on Teacher Education in the Digital Age. IGI Global, Hershey, PA, USA. pp. $412-438$.

Edwards-Groves, C., Grootenboer, P., \& Smith, T. (2018). Knowing pedagogical practice in twenty-first century education. In Edwards-Groves, C., Grootenboer, P., Wilkenson, J. (Ed.s) Education in an Era of Schooling. Springer, Singapore.

Hamilton, D., Márquez, P., \& Agger-Gupta, N. (2013). RRU learning \& teaching model. Available at:

http://media.royalroads.ca/media/marketing/viewbooks/2013/learningmodel/?pageNumber=1 (accessed 15 October 2020)

Hamilton, D., Márquez, P., \& Agger-Gupta, N. (2016). Living our learning: chronicling the implementation of an institutional educational framework. In Grundy, S., 
Hamilton, D., Veletsianos, G., Agger-Gupta, N., Márquez, P., Forssmann, V., \& Legault, M. (Ed.s). Engaging students in life-changing learning: the Royal Roads University learning and teaching model in practice. pp. 17-30. Available at: https://learningandteachingmodel.pressbooks.com/ (accessed 15 October 2020) Harris, B., Walinga, J., Childs, E., Raby, J., Takach, G., Jorgensen, F., . . Forssman, V. (2019). Cultivating change leaders for a better world: learning teaching and research model. Available at: https://ctet.royalroads.ca/sites/default/files/pages/ltrm fullreferenceguide webcompressed.pdf (accessed 15 October 2020)

Ivankova, N. (2015). Mixed methods applications in action research. Sage, London, UK. Kemmis, S. (2010). Research for praxis: knowing doing. Pedagogy, Culture \& Society Vol 18 No 1. pp. 9-27. Available at: https://doi.org/10.1080/14681360903556756 (accessed 15 October 2020)

Kemmis, S. (2012). Researching educational praxis: spectator and participant perspective. British Educational Research Journal, Vol 38 No 6. pp. 885-905.

Lichtenstein, B. (2015). Complex systems and emergence in action research. In Bradbury, H. (Ed.) The Sage Handbook of Action Research. (3 $3^{\text {rd }}$ ed.) Sage, London, UK. pp. 446-452.

Looker, P. (2005). Learning through structured reflection. UNSW Compendium of Good Practice in Learning and Teaching (2), pp. 68-81.

Mount Royal University. (2019). Planning to Flourish. Mount Royal University's strategic plan to 2025. Available at: 
https://www.mtroyal.ca/AboutMountRoyal/OfficesGovernance/_pdfs/gfc_academi cplan2017-22.pdf (accessed 15 October 2020)

Queens University. (2014). Teaching and learning action plan. Available at: http://www.queensu.ca/provost/sites/webpublish.queensu.ca.provwww/files/files/ TeachingAndLearningActionPlanMarch2014.pdf (accessed 15 October 2020) Robertson, A. (2016). Developing a new whole institutional approach to teaching and learning enhancement: a case study from Abertay University. Higher Education Academy. Available at:

https://www.heacademy.ac.uk/sites/default/files/downloads/developing a new w hole institutional_approach to teaching_and_learning_enhancement_abertay university.pdf (accessed 15 October 2020)

Silverman, H. (2015). Designerly ways for action research. In H. Bradbury (Ed.). The Sage Handbook of Action Research ( $3^{\text {rd }}$ ed.) Sage, London, UK.

Steel, A., \& Jeffreys, G. (2006). Building a curriculum framework: law, lawyers and society. Available at: https://works.bepress.com/alex steel/35/ (accessed 15 October 2020)

Stensaker, B., Bilbow, G. T., Breslow, L., \& van der Vaart, R. (2017). Strategic challenges in the development of teaching and learning in research-intensive universities. In Stensaker, B., Bilbow, G. T., Breslow, L., \& van der Vaart, R. (Ed.s). Strengthening teaching and learning in research universities: strategies and initiatives for institutional change. pp. 1-18.

Stringer, E. T. (2014). Action research (4th ed.). Sage, London, UK. 
University of Calgary. (2011). Eyes high: 2011 vision and strategy. Available at: https://ucalgary.ca/research/files/research/eyes high-2011-vision-andstrategy.pdf (accessed 15 October 2020)

University of Calgary. (2014). Strategic framework for learning technologies. Available at:_ https://silo.tips/download/strategic-framework-for-learning-technologies (accessed 15 October 2020)

University of Melbourne. (n.d.). Resources for teachers. Available at: https://arts.unimelb.edu.au/teaching-and-learning/resources-for-teachers (accessed 15 October 2020)

University of Melbourne. (2007). Nine principles guiding teaching and learning: the framework for a first-class university teaching and learning environment. Available at: https://arts.unimelb.edu.au/ data/assets/pdf file/0004/1722433/9principles.pdf (accessed 15 October 2020)

University of New South Wales. (2014). Guidelines on learning that inform teaching at UNSW. Sydney: UNSW Learning and Teaching Unit. Available at: https://teaching.unsw.edu.au/guidelines (accessed 15 October 2020) University of New South Wales. (2019). Guidelines on learning. Available at: https://teaching.unsw.edu.au/guidelines (accessed 15 October 2020) University of Sydney. (2016). The University of Sydney 2016-20 strategic plan. Available at: $\underline{\text { http://sydney.edu.au/dam/intranet/documents/strategy-and- }}$ planning/strategic-plan-2016-20.pdf (accessed 15 October 2020)

University of the Western Cape. (n.d.). Graduate attributes and the strategic plan for teaching and learning. Available at: 
https://www.uwc.ac.za/TandL/Pages/Graduate-Attributes.aspx (accessed 15

October 2020)

Zimmerman, B., Reason, P., Rykert, L., Gitterman, L., Christian, J., \& Gardam, M. (2013). Front-line ownership: generating a cure mindset for patient safety. Healthcare Papers, Vol 13 No 1. p. 6. 


\section{Article reviewer comments and response}

Note: the feedback from R1 conflicts with the comments from the other 3 reviewers. This has been considered in the Authors' Reponses below.

\begin{tabular}{|c|c|c|}
\hline & Reviewer's Comments & Authors' response \\
\hline \multirow[t]{5}{*}{$\begin{array}{l}\text { Comments/ } \\
\text { Recommendation }\end{array}$} & $\begin{array}{l}\text { (R1) This is clearly a serious research. A well written and } \\
\text { structured paper. It needs to develop more some } \\
\text { literature review regarding some fundamentals about } \\
\text { quality learning, teaching \& research in the } 21 \text { century. }\end{array}$ & $\begin{array}{l}\text { Thank you for the comment. The suggested review of } \\
\text { literature would be a great focus for a separate paper. The } \\
\text { focus of this article is on an engagement process for } \\
\text { developing a strategic document on learning, teaching and } \\
\text { research. It was not meant to be a commentary on quality } \\
\text { in learning and teaching. To address this comment would } \\
\text { change the purpose of the article and go beyond the } \\
\text { current word count limits. }\end{array}$ \\
\hline & $\begin{array}{l}\text { (R2) The paper would be of more interest if the value of } \\
\text { the process and the realization of the model produced } \\
\text { were detailed in some way. It would be good to include } \\
\text { more context for the work, the motivations and also to } \\
\text { give an overview of what the outcomes were. }\end{array}$ & $\begin{array}{l}\text { All of these addressed: introduction rewritten, more } \\
\text { details about the process in the methods, motivations } \\
\text { more clearly articulated in the introduction and methods, } \\
\text { outcomes were clarified. }\end{array}$ \\
\hline & $\begin{array}{l}\text { (R3) Can you please add more elaboration as to the } \\
\text { process for the } 5 \text { attributes that was selected to be } \\
\text { research on. }\end{array}$ & $\begin{array}{l}\text { Revised in the methods section re: working group } \\
\text { deliberation on the data; the testing of attributes in the } \\
\text { Phase } 2 \text { follow-up survey that went back to the } \\
\text { stakeholders for their feedback and they confirmed that } \\
\text { they resonated with them. } \\
\text { Note, the attributes were not selected, they emerged from } \\
\text { the data as per the thematic analysis conducted. }\end{array}$ \\
\hline & $\begin{array}{l}\text { (R4) It would be helpful for readers across the globe if } \\
\text { some major problems occurred during streamlining LTRM. }\end{array}$ & $\begin{array}{l}\text { Added in the Reflections and Implications for Practice } \\
\text { section at the end of the paper. }\end{array}$ \\
\hline & $\begin{array}{l}\text { (R1) The objective of this action research comes in a } \\
\text { Quality Assurance Review Framework that is very common } \\
\text { in most if not all Higher Education institutions around the } \\
\text { world. This process usually reviews and reports about the }\end{array}$ & $\begin{array}{l}\text { We have clarified that this is not a QA process. The LTM } \\
\text { and LTRM were not developed to be a QA process. The } \\
\text { university has QA processes and procedures, but this is not } \\
\text { the focus of this article. Rather, this article details an } \\
\text { action research process focused on building a learning and }\end{array}$ \\
\hline
\end{tabular}




\begin{tabular}{|c|c|c|}
\hline & $\begin{array}{l}\text { Quality in Learning, Teaching and Research offered by the } \\
\text { University. }\end{array}$ & $\begin{array}{l}\text { teaching framework through practitioner conversations, } \\
\text { and benefits resulting from them. }\end{array}$ \\
\hline & $\begin{array}{l}\text { (R2) No real reflection in the paper on what the issues } \\
\text { were or the motivations for the work and why the } \\
\text { framework they designed was needed. The methods and } \\
\text { process of stakeholder involvement is interesting but } \\
\text { perhaps not new or significant in terms of how you might } \\
\text { go about enacting change and developing a framework for } \\
\text { teaching, learning and research on an institution-wide } \\
\text { scale. }\end{array}$ & $\begin{array}{l}\text { These have been added and/or strengthened. See the } \\
\text { introduction, Action Research Design and Reflection and } \\
\text { Implications for Practice sections. }\end{array}$ \\
\hline & $\begin{array}{l}\text { (R3) Yes this paper has provided more evidence on the use } \\
\text { of action research and authentic discussions in the } \\
\text { creation and establishing a relevant Institutional } \\
\text { framework for the teaching/learning and research process. }\end{array}$ & Thank you for your comment. \\
\hline & $\begin{array}{l}\text { (R4) Yes. The manuscript offers how an institute can } \\
\text { develop a Learning, Teaching and Research Model as the } \\
\text { prototype model was developed at Royal Roads University } \\
\text { (RRU). }\end{array}$ & Thank you for your comment. \\
\hline Literature & $\begin{array}{l}\text { (R1) The paper made use of some important conceptual } \\
\text { frameworks but it was very brief, it should me more } \\
\text { developed especially in reviewing the purpose of } \\
\text { monitoring and evaluating learning, teaching \& research } \\
\text { practices in Higher education; in reviewing literature } \\
\text { regarding the practice/praxis framework; contextual } \\
\text { teaching and learning; real-world learning or context- } \\
\text { based adult learning (Brundiers, Wiek, \& Redman } \\
\text { Jonhnson); cooperative learning (Davidson, Peterson \& } \\
\text { Miller), social interaction \& its relation to learning (Strauss } \\
\text { \& Ziv, Battro); metacognition \& self-regulated learning } \\
\text { (Zimmerman \& } \\
\text { Moylan; (Spruce \& Bol); project-based learning (Bell, S) }\end{array}$ & $\begin{array}{l}\text { The intention this literature review was to provide an } \\
\text { overview of the various ways institutions use learning and } \\
\text { teaching frameworks. As well, we reviewed literature on } \\
\text { action research since the article focused on the research } \\
\text { design. Therefore, the emphasis on monitoring and } \\
\text { evaluating learning was not within scope. However, this } \\
\text { would be a great focus for future work. }\end{array}$ \\
\hline
\end{tabular}




\begin{tabular}{|c|c|c|}
\hline & $\begin{array}{l}\text { (R2) The background literature review of frameworks is } \\
\text { fine. I don't think any significant work has been ignored. }\end{array}$ & Thank you for your comment. \\
\hline & $\begin{array}{l}\text { (R3) The literature selected and discussed are relevant to } \\
\text { the issues being investigated. }\end{array}$ & Thank you for your comment. \\
\hline & $\begin{array}{l}\text { (R4) Yes. The reviewed literature is properly placed and } \\
\text { integrated in the manuscript. }\end{array}$ & Thank you for your comment. \\
\hline \multirow[t]{4}{*}{ Methodology } & $\begin{array}{l}\text { (R1) Yes, but as mentioned above need more } \\
\text { development; Yes and it is well explained. But what is } \\
\text { missing is a description of the samples who participated in } \\
\text { the focus groups and design thinking (number, positions, } \\
\text { etc.) } \\
\text { Yes the methods are appropriate. }\end{array}$ & $\begin{array}{l}\text { Roles and positions were outlined in Table 3: Data } \\
\text { Collection activity and abbreviations. Since we achieved } \\
\text { data saturation, numbers were not included. }\end{array}$ \\
\hline & $\begin{array}{l}\text { (R2) Theoretical background is sound, outline of methods } \\
\text { is ok too, as are the research methods used to elicit } \\
\text { feedback and engage stakeholders. However, I think the } \\
\text { paper lacks rigour and data to support findings. Limitations } \\
\text { of approach are not recognised. }\end{array}$ & $\begin{array}{l}\text { Rigour is addressed directly in the research approach } \\
\text { section, noting that the action research design allowed } \\
\text { provided a considerable foundation of an established } \\
\text { research tradition, philosophy and processes. As well, } \\
\text { Phase } 2 \text { of the research was to verify the working group's } \\
\text { interpretation of the data and the resonance of the } \\
\text { prototype with the university community. } \\
\text { Limitations have been addressed in the concluding section. }\end{array}$ \\
\hline & $\begin{array}{l}\text { (R3) The methodology selected is appropriate for the goals } \\
\text { of the research and robust enough to answer the research } \\
\text { question and objectives. The justifications and } \\
\text { clarifications of selecting and utilizing the Methodology } \\
\text { was very comprehensive. But perhaps the explanation for } \\
\text { selecting the five attributes to be investigated in the } \\
\text { research can be further elaborated. }\end{array}$ & $\begin{array}{l}\text { Thank you. The analysis process that led to the categories } \\
\text { and their attributes has been expanded. }\end{array}$ \\
\hline & $\begin{array}{l}\text { (R4) Methodology goes well in context of the model } \\
\text { proposed in the document. }\end{array}$ & Thank you for your comment. \\
\hline \multirow[t]{2}{*}{ Results } & (R1) Yes, well presented and clear. & Thank you for your comment. \\
\hline & $\begin{array}{l}\text { (R2) It is not really clear what the end result was and how } \\
\text { the new learning, teaching and research model was } \\
\text { realised tangibly. There is no real overview of the model }\end{array}$ & $\begin{array}{l}\text { To provide an overview of the LTRM model and how it } \\
\text { works in practice was not the intent of this paper. That will } \\
\text { be addressed in subsequent papers. We have added clarity }\end{array}$ \\
\hline
\end{tabular}




\begin{tabular}{|c|c|c|}
\hline & $\begin{array}{l}\text { and how it works in practice. I recognise that they are } \\
\text { describing the process but more on the outcomes would } \\
\text { strengthen the paper. }\end{array}$ & $\begin{array}{l}\text { to how the outcomes are presented (as the prototype) and } \\
\text { how they were arrived at. }\end{array}$ \\
\hline & $\begin{array}{l}\text { (R3) The results, summary and conclusions of this research } \\
\text { is clear and have been analyzed appropriately. }\end{array}$ & Thank you for your comment. \\
\hline & $\begin{array}{l}\text { (R4) Its a kind of open action research. Methodology goes } \\
\text { well in context of the model proposed in the document. }\end{array}$ & Thank you for your comment. \\
\hline \multirow[t]{4}{*}{$\begin{array}{l}\text { Implications for } \\
\text { research, practice, } \\
\text { society }\end{array}$} & $\begin{array}{l}\text { (R1) It may be if it is addressed to higher education } \\
\text { institutions that are beginning to review \& evaluate their } \\
\text { LTRM. } \\
\text { Does not clearly the gap between theory and practice? } \\
\text { Are the implications consistent with the findings and } \\
\text { conclusions of the paper? Needs to be better clarified in } \\
\text { the purpose of the study. }\end{array}$ & $\begin{array}{l}\text { This conflicts with the other three reviewers; however, we } \\
\text { have strengthened the implications mentioned in the } \\
\text { Conclusion section. } \\
\text { However, purpose and implications have been revised. }\end{array}$ \\
\hline & $\begin{array}{l}\text { (R2) The paper does not really identify clear implications } \\
\text { for research but does outline some good methods for } \\
\text { engaging stakeholders. It is not clear how the research can } \\
\text { be used in practice though. We need to know the detail of } \\
\text { the outcomes in order to determine the value of the } \\
\text { approach to others. }\end{array}$ & $\begin{array}{l}\text { We have clarified the purpose and have reviewed the } \\
\text { implications and tightened them accordingly. }\end{array}$ \\
\hline & $\begin{array}{l}\text { (R3) As the methodology selected was to represent an } \\
\text { authentic action research, it has managed to collect very } \\
\text { relevant data that is tied to the institution where this } \\
\text { research was conducted. Therefore the implications are } \\
\text { very closely related to the institution in itself. But the } \\
\text { process can be easily generalized and implemented at } \\
\text { other institutions }\end{array}$ & $\begin{array}{l}\text { Thank you for your comment. This has been explicitly } \\
\text { addressed in the final section of the paper. }\end{array}$ \\
\hline & $\begin{array}{l}\text { (R4) The refinement of LTRM took two years. There must } \\
\text { be a lot of issues/hindrances in between which were } \\
\text { resolved/cleared to streamline the proposed model. It } \\
\text { would be more informative if author would incorporate a } \\
\text { section like 'problems faced' to highlight some of the } \\
\text { major problems and how RRU addressed those. }\end{array}$ & $\begin{array}{l}\text { Problems faced have been discussed and included in the } \\
\text { paper (completing project due to time/logistics/size). See } \\
\text { comment above. }\end{array}$ \\
\hline Quality of & (R1) The Quality of communication is satisfying. & Revised. Thank you. \\
\hline
\end{tabular}




\begin{tabular}{|l|l|l|}
\hline Communication & $\begin{array}{l}\text { (R1) p. } 9 \text { Line 33 - 36: A sentence not clear "Are these } \\
\text { implications consistent with the findings and conclusions } \\
\text { of the paper?" } \\
\text { A mistake on p. 12, line 20 "Staff Observed" }\end{array}$ & \\
\cline { 2 - 3 } & $\begin{array}{l}\text { (R2) The paper is well written and uses clear language and } \\
\text { is at the level expected for the journal's readership. It just } \\
\text { needs more detail. }\end{array}$ & We have provided more detail. \\
\cline { 2 - 3 } & $\begin{array}{l}\text { (R3) The quality of the communication is excellent and at } \\
\text { the quality expected for an international research journal. } \\
\text { The authors have managed to present their information } \\
\text { with clarity and at an academic level that is easily } \\
\text { understood. }\end{array}$ & Thank you for your comment. \\
\hline & $\begin{array}{l}\text { (R4) Quality of the communication is good and giving a } \\
\text { proper flow while one reads it. }\end{array}$ & Thank you for your comment. \\
\hline
\end{tabular}




\section{Table 1}

LTRM Design as Action Research Cycles and Design Thinking Stages

\section{Phase Activity Action research cycle Design stages}

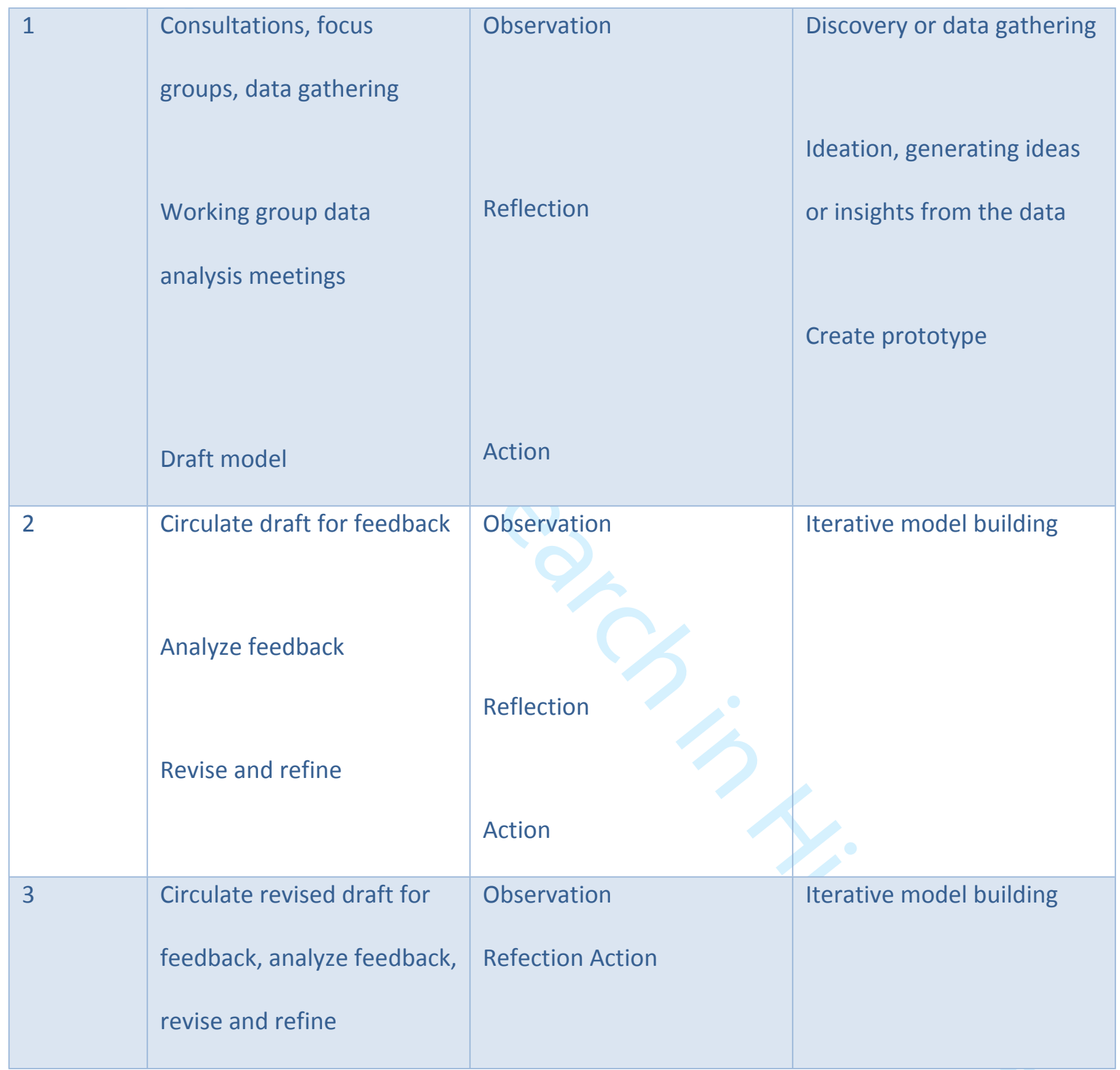




\section{Table 2}

From Cultivating Change Leaders for a Better World: The Learning Teaching and Research Model (2019).

10

11

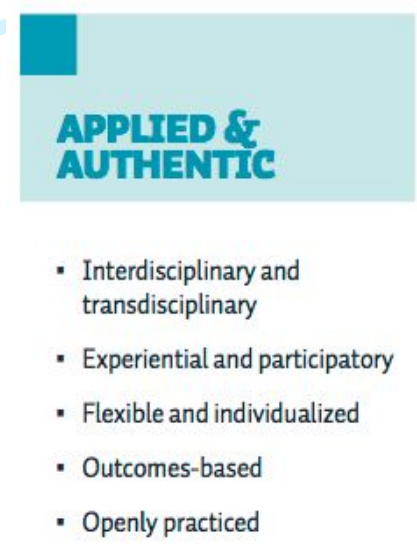

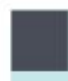

\section{TRANSFORMATIONAL}

- Inclusive and diverse

- Community-based learning

- Supportive

- Team-based

- Co-creative

- Place- and virtual space-based
- Socially innovative

- Respectful of Indigenous Peoples and traditions

- Impactful

- Reflective 


\section{Table 3}

Data Collection Activity and Abbreviations

\begin{tabular}{|c|c|c|c|c|}
\hline Phase & Activity & Participants/Topic & Data & $\begin{array}{l}\text { Source } \\
\text { notation }\end{array}$ \\
\hline \multirow[t]{8}{*}{1} & Maker Day & Faculty, staff, alumni & $\begin{array}{l}\text { Photographs, } \\
\text { flip chart } \\
\text { summary } \\
\text { notes }\end{array}$ & Maker Day \\
\hline & $\begin{array}{l}\text { LTRM } \\
\text { campus- } \\
\text { wide activity }\end{array}$ & Faculty and staff & Padlet notes & $\begin{array}{l}\text { LTRM } \\
\text { activity }\end{array}$ \\
\hline & $\begin{array}{l}\text { Focus } \\
\text { Groups }\end{array}$ & $\begin{array}{l}\text { Faculty and staff discussing } \\
\text { Research } \\
\text { Faculty }\end{array}$ & \multirow{6}{*}{$\begin{array}{l}\text { flip chart } \\
\text { summary } \\
\text { notes } \\
\text { Padlet } \\
\text { comments }\end{array}$} & $\begin{array}{l}\text { Research } \\
\text { FG } \\
\text { Faculty FG }\end{array}$ \\
\hline & & $\begin{array}{l}\text { raculty } \\
\text { Staff }\end{array}$ & & $\begin{array}{l}\text { raculty FG } \\
\text { Staff FG }\end{array}$ \\
\hline & & Students & & Student FG \\
\hline & & Alumni & & Alumni FG \\
\hline & & Student services staff & & SS FG \\
\hline & & Faculty and Staff & & $\begin{array}{l}\text { LTRM } \\
\text { Session }\end{array}$ \\
\hline $1 \& 2$ & $\begin{array}{l}\text { Presentation } \\
\text { and } \\
\text { feedback }\end{array}$ & School advisory councils & $\begin{array}{l}\text { Comments } \\
\text { sent to the } \\
\text { working group }\end{array}$ & AC feedback \\
\hline
\end{tabular}




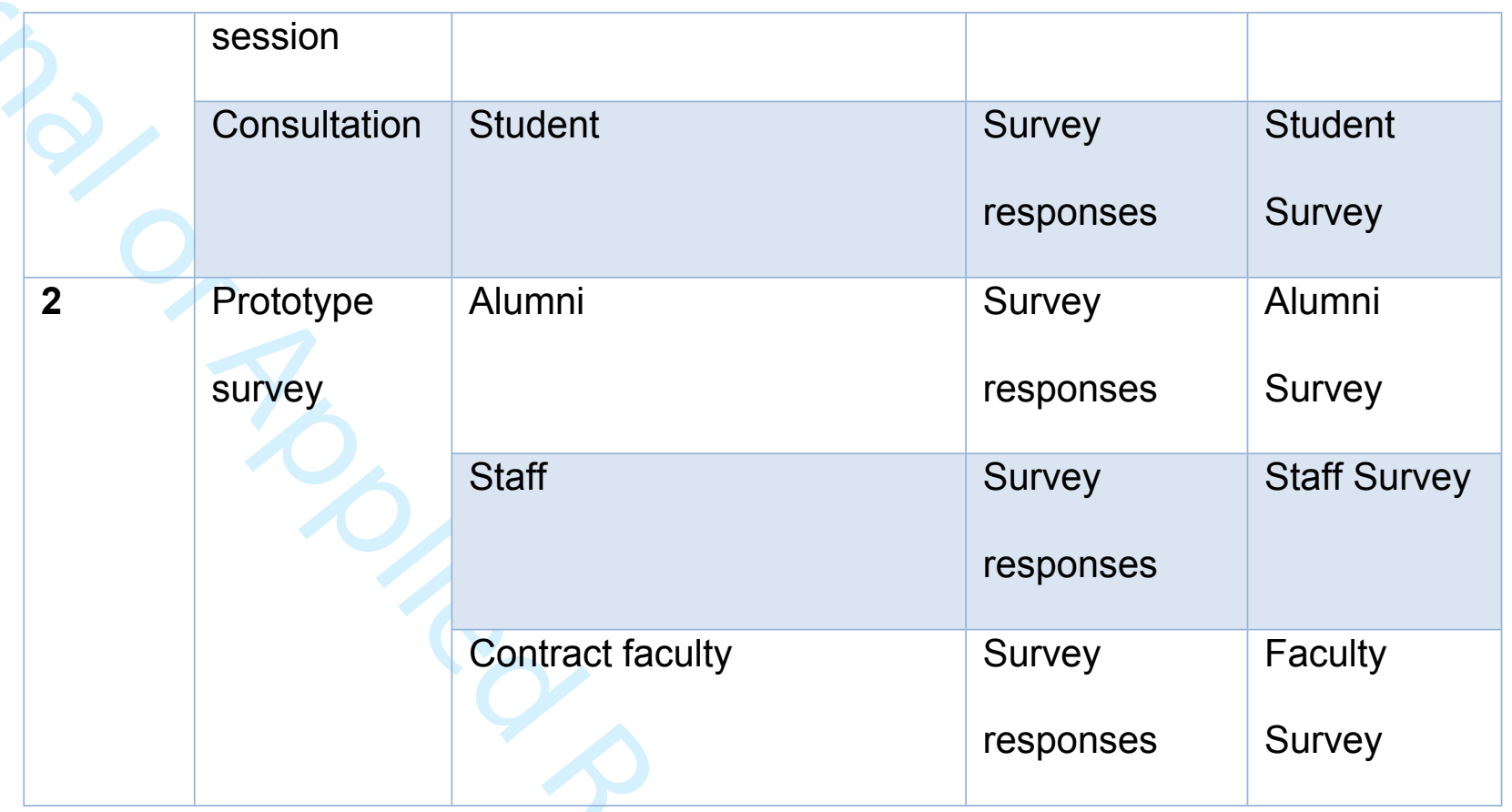

